\title{
Survival and predictive factors in dialysis patients with COVID-19 in Japan: a nationwide cohort study
}

\author{
Kan Kikuchi ${ }^{1 *}$, Masaomi Nangaku ${ }^{2}$, Munekazu Ryuzaki ${ }^{3}$, Tomoyuki Yamakawa ${ }^{4}$, Oota Yoshihiro ${ }^{5}$, \\ Norio Hanafusa ${ }^{6}$, Ken Sakai ${ }^{7}$, Yoshihiko Kanno ${ }^{8}$, Ryoichi Ando ${ }^{9}$, Toshio Shinoda ${ }^{10}$, Hidetomo Nakamoto ${ }^{11}$ and \\ Tadao Akizawa ${ }^{12}$ COVID-19 Task Force Committee of the Japanese Association of Dialysis Physicians, the \\ Japanese Society for Dialysis Therapy, and the Japanese Society of Nephrology
}

\begin{abstract}
Background: The Japanese Association of Dialysis Physicians, the Japanese Society for Dialysis Therapy, and the Japanese Society of Nephrology jointly established COVID-19 Task Force Committee and began surveying the number of newly infected patients.

Methods: This registry of the COVID-19 Task Force Committee was used to collect data of dialysis patients; a total of 1010 dialysis patients with COVID-19 were included in the analysis. Overall survival of patients was investigated with stratification by age group, complication status, and treatment. In addition, predictive factors for mortality were also investigated. The overall survival was estimated by Kaplan-Meier methods and compared by using log-rank test. Multivariate analysis was performed to identify the risk factor of mortality. For all statistical analyses, $p<0.05$ was considered to be statistically significant.

Results: The mortality risk was increased with age $(p<0.001)$. The mortality risk was significantly higher in patients with peripheral arterial disease (HR: $1.49,95 \% \mathrm{Cl} 1.05-2.10)$ and significantly lower in patients who were treated with remdesivir (HR: 0.60, 95\% Cl 0.37-0.98). Multivariate analysis showed increased risk of mortality with increment in BMI, and increment in CRP, and decreased risk with increment in albumin.

Conclusion: Dialysis patients have a high severity of illness and a high risk of mortality in cases of COVID-19. Treatment with remdesivir might be effective in shortening the duration of hospitalization and reducing the risk of mortality.
\end{abstract}

Keywords: COVID-19, SARS-CoV-2, Dialysis, Peritoneal dialysis, Remdesivir

\section{Background}

In 2019, the new coronavirus disease (COVID-19) emerged from Wuhan, Hubei Province, China, and has rapidly spread around the world. The World Health

*Correspondence: kankikuchi@nifty.com

${ }^{1}$ Division of Nephrology, Shimoochiai Clinic, 2-1-6 Shimoochiai, Shinjuku-ku, Tokyo 161-0033, Japan

Full list of author information is available at the end of the article
Organization declared it to be a pandemic on March 11, 2020. As of August 14, 2021, there were 205,338,159 COVID-19 cases and 4,333,094 deaths worldwide [1].

In the general population of Japan, the first case of severe acute respiratory syndrome coronavirus 2 (SARSCoV-2) was detected on January 15, 2020, in a patient with pneumonia who had traveled to Wuhan City. Since then, we have experienced a rapid increase in the number of new patients with COVID-19 from the first wave original author(s) and the source, provide a link to the Creative Commons licence, and indicate if changes were made. The images or other third party material in this article are included in the article's Creative Commons licence, unless indicated otherwise in a credit line to the material. If material is not included in the article's Creative Commons licence and your intended use is not permitted by statutory regulation or exceeds the permitted use, you will need to obtain permission directly from the copyright holder. To view a copy of this licence, visit http://creativecommons.org/licenses/by/4.0/. The Creative Commons Public Domain Dedication waiver (http://creativecommons.org/publicdomain/zero/1.0/) applies to the data made available in this article, unless otherwise stated in a credit line to the data. 
to the fifth wave, with a total of 1,108,269 COVID-19 cases and 15,383 deaths reported as of August 14, 2021 [2]. In the dialysis patients, on the other hand, the first patient with COVID-19 was reported on March 1, 2020. Soon after that, the Japanese Association of Dialysis Physicians, the Japanese Society for Dialysis Therapy, and the Japanese Society of Nephrology jointly established COVID-19 Task Force Committee to survey the number of newly infected patients and create guidance on preventive measures for COVID-19 for raising awareness [3]. The fifth wave began in Japan in July 2021, and a rapid increase in the number of newly infected dialysis patients was observed, with a cumulative total of 2156 infected dialysis patients as of August 12, 2021 [4].

The COVID-19 Task Force Committee summarized the infection situation among dialysis patients in Japan in 2020 and reported that severity and mortality rate were higher in the dialysis patients compared to that in the general population [3]. In this manuscript, we report the results of the risk factors of mortality and the effect of treatment in Japanese dialysis patients with COVID-19 up to the end of the fourth wave.

\section{Methods}

\section{Subjects and data}

Surveillance of new cases of COVID-19 in dialysis facilities in Japan was initiated by the COVID-19 Task Force Committee of the Japanese Association of Dialysis Physicians, the Japanese Society for Dialysis Therapy, and the Japanese Society of Nephrology on April 8, 2020 [3]. This registry was used to collect data of dialysis patients; data of a total of 1,948 dialysis patients with COVID-19 who were registered by June 19, 2021, were extracted. Among those, data of 897 patients (893 patients whose outcome was unknown and 4 patients whose age was unknown) were excluded, and a total of 1010 patients were included in this analysis.

Patient background data (age, gender, primary disease, duration of dialysis, complications, oxygenation, treatment for COVID-19) were collected; however, smoking status data were not collected. Blood test data at the time of diagnosis or hospitalization [albumin, blood urea nitrogen, creatinine, C-reactive protein (CRP), white blood cell count, hemoglobin, and platelet count] were available in patients who registered after March 16, 2021; these data were collected from a total of 311 patients whose blood test data were available. Treatment policy by the Ministry of Health, Labour and Welfare in Japan was implemented in which dialysis patients diagnosed with COVID-19 are treated with hospitalization [3].

Overall survival of patients was investigated with stratification by age group, complication status, and treatment. In terms of treatment for COVID-19, the efficacy of remdesivir was investigated among matched patients by using propensity score for age and oxygenation [with or without oxygen supplementation, ventilator, or extracorporeal membrane oxygenation (ECMO)] at the ratio of 1:3 for the patient group treated with remdesivir and the patient group not treated with remdesivir. The duration of hospitalization was also compared between the patient group treated with remdesivir and the patient group not treated with remdesivir. In terms of dialysis, overall survival was compared between patients who underwent peritoneal dialysis and those who underwent hemodialysis matched using the propensity score for age and oxygenation (with or without oxygen supplementation, ventilator, or ECMO) at the ratio of 1:3.

\section{Statistical analysis}

Categorical data were analyzed using Fisher's exact test, and continuous data were analyzed using Welch's $t$ test or Mann-Whitney's U-test. For survival analysis, the survival probability was estimated by Kaplan-Meier methods and compared using log-rank test. The multiplicity was adjusted by Bonferroni method. Hazard ratios and associated $95 \%$ confidence intervals were assessed by Cox regression hazard model.

The univariate and multivariate analyses were performed to identify the risk factor of mortality, with incidence of COVID-19 in facilities (less than 5 or more than 5$)$, age $(<60,60 \mathrm{~s}$, or $\geq 70)$, gender, primary disease (chronic glomerulonephritis, diabetes mellitus, nephrosclerosis, or others), duration of dialysis ( $<1$ year, 1 to $<5$ years, 5 to $<10$ years, 10 to $<15$ years, or $\geq 15$ years), complications (diabetes mellitus, hypertension, cardiovascular disease, peripheral arterial disease, or malignancy), oxygenation (with or without oxygen supplementation, ventilator, or ECMO), treatment for COVID-19 (with or without remdesivir or dexamethasone) as independent variables. The univariate and multivariate analyses were performed to identify the risk factors of mortality also in those who had blood test data at the time of diagnosis or hospitalization, with age $(<60$, $60 \mathrm{~s}$, or $\geq 70$ ), gender, primary disease (chronic glomerulonephritis, diabetes mellitus, nephrosclerosis, or others), duration of dialysis ( $<1$ year, 1 to $<5$ years, 5 to $<10$ years, 10 to $<15$ years, or $\geq 15$ years), BMI, albumin, blood urea nitrogen, creatinine, CRP, white blood cell count, hemoglobin, and platelet count as independent variables.

All analyses were performed using SPSS Statistics version 21 (IBM SPSS Statistics for Windows, IBM, Armonk, $\mathrm{NY}$ ), and $p<0.05$ was considered to be statistically significant. This study was approved by the Ethics Committee of the Japanese Society for Dialysis Therapy (authorization number: 1-8), and all procedures adhered to the Declaration of Helsinki. 


\section{Results}

\section{Comparison of patient background between patient groups who recovered and who died}

The patient background and blood test data of patient groups of those who were recovered and those who died are shown in Tables 1 and 2, respectively. Among 1010 patients included in this analysis, 699 patients (69.2\%) recovered and 311 patients $(30.8 \%)$ died. The age was higher and duration of dialysis was longer in the patient group who died; however, there was no difference in gender or primary disease for induction of dialysis between groups. In terms of complications, the proportions of patients with cardiovascular disease and peripheral arterial disease were higher in the patient group who died. Moreover, the proportion of patients who had oxygenation, or treated with dexamethasone was higher in the patient group who died. Among 311 patients whose blood test data were available, body mass index (BMI), creatinine, and albumin were lower and CRP was higher in the patient group who died.

\section{Survival of patients stratified by age group, complication status, and treatment for COVID-19}

Comparison of overall survival of patients stratified by age group $(<60,60 \mathrm{~s}$, or $\geq 70)$ showed that the mortality risk was increased with age $(p<0.001)$ (Fig. 1). According to the univariate analysis, the mortality risk was significantly higher in the patient group with age $60 \mathrm{~s}$ [hazard ratio (HR): 2.02, 95\% confident interval (CI) 1.27-3.23)] and in the patient group with age $\geq 70$ (HR: 3.13, 95\% CI 3.13-6.77) when comparing to the patient group with age $<60$. According to the multivariate analysis, the mortality risk was significantly higher in the patient group with age $\geq 70$ (HR: 4.92, 95\% CI 3.10-7.80) but not in the patient group with age $60 \mathrm{~s}$ (HR: 1.58 , 95\% CI 0.90$2.77)$ when comparing to the patient group with age $<60$ (Table 3).

The multivariate analysis also showed significant increase in mortality with prolonging duration of dialysis; however, there was no difference in gender or primary disease. The mortality risk was significantly higher in patients with peripheral arterial disease (HR: $1.49,95 \%$ CI 1.05-2.10) in terms of complication and was significantly lower in patients who were treated with remdesivir (HR: $0.60,95 \%$ CI $0.37-0.98$ ) in terms of treatment for COVID-19 (Table 3).

\section{Efficacy of remdesivir}

A total of 392 patients were analyzed (98 patients who were treated with remdesivir and matched 294 patients who were not treated with remdesivir); the background
Table 1 Background of patients

\begin{tabular}{|c|c|c|c|c|c|}
\hline & \multicolumn{2}{|c|}{ Recovered } & \multicolumn{2}{|c|}{ Died } & \multirow[t]{2}{*}{$p$ value $^{a}$} \\
\hline & $n$ & $\%$ & $n$ & $\%$ & \\
\hline \multicolumn{6}{|l|}{ Age } \\
\hline$<60$ & 250 & 35.8 & 29 & 9.3 & $<0.001$ \\
\hline $60 s$ & 164 & 23.5 & 45 & 14.5 & \\
\hline$\geq 70$ & 285 & 40.8 & 237 & 76.2 & \\
\hline \multicolumn{6}{|l|}{ Gender } \\
\hline Male & 497 & 71.3 & 212 & 68.4 & 0.37 \\
\hline Female & 200 & 28.7 & 98 & 31.6 & \\
\hline \multicolumn{6}{|l|}{ Primary disease } \\
\hline Chronic glomerulonephritis & 123 & 19.4 & 37 & 13.8 & 0.211 \\
\hline Diabetes mellitus & 328 & 51.8 & 147 & 54.6 & \\
\hline Nephrosclerosis & 87 & 13.7 & 43 & 16.0 & \\
\hline Others & 95 & 15.0 & 42 & 15.6 & \\
\hline \multicolumn{6}{|l|}{ Duration of dialysis } \\
\hline$<1$ year & 95 & 13.9 & 21 & 7.5 & 0.015 \\
\hline 1 to $<5$ years & 257 & 37.6 & 94 & 33.7 & \\
\hline 5 to $<10$ years & 164 & 24.0 & 78 & 28.0 & \\
\hline 10 to $<15$ years & 83 & 12.1 & 45 & 16.1 & \\
\hline$\geq 15$ years & 85 & 12.4 & 41 & 14.7 & \\
\hline \multicolumn{6}{|l|}{ Complication } \\
\hline \multicolumn{6}{|l|}{ Hypertension } \\
\hline No & 383 & 56.2 & 158 & 57.0 & 0.83 \\
\hline Yes & 299 & 43.8 & 119 & 43.0 & \\
\hline \multicolumn{6}{|l|}{ Diabetes mellitus } \\
\hline No & 335 & 48.4 & 120 & 42.7 & 0.119 \\
\hline Yes & 357 & 51.6 & 161 & 57.3 & \\
\hline \multicolumn{6}{|l|}{ Cardiovascular disease } \\
\hline No & 420 & 62.5 & 131 & 48.9 & $<0.001$ \\
\hline Yes & 252 & 37.5 & 137 & 51.1 & \\
\hline \multicolumn{6}{|l|}{ Chronic respiratory disease } \\
\hline No & 625 & 92.5 & 243 & 89.3 & 0.122 \\
\hline Yes & 51 & 7.5 & 29 & 10.7 & \\
\hline \multicolumn{6}{|l|}{ Peripheral arterial disease } \\
\hline No & 585 & 87.3 & 198 & 74.7 & $<0.001$ \\
\hline Yes & 85 & 12.7 & 67 & 25.3 & \\
\hline \multicolumn{6}{|l|}{ Malignancy } \\
\hline No & 586 & 86.8 & 226 & 84.0 & 0.298 \\
\hline Yes & 89 & 13.2 & 43 & 16.0 & \\
\hline \multicolumn{6}{|l|}{ Number of complications } \\
\hline 0 & 114 & 16.5 & 29 & 10.2 & 0.008 \\
\hline 1 & 218 & 31.5 & 80 & 28.2 & \\
\hline$\geq 2$ & 361 & 52.1 & 175 & 61.6 & \\
\hline \multicolumn{6}{|l|}{ Oxygenation } \\
\hline No & 302 & 44.8 & 29 & 10.5 & $<0.001$ \\
\hline Yes & 320 & 47.5 & 174 & 63.0 & \\
\hline Ventilator or ECMO & 52 & 7.7 & 73 & 26.4 & \\
\hline \multicolumn{6}{|l|}{ Remdesivir } \\
\hline No & 591 & 89.0 & 235 & 90.0 & 0.723 \\
\hline Yes & 73 & 11.0 & 26 & 10.0 & \\
\hline
\end{tabular}


Table 1 (continued)

\begin{tabular}{|c|c|c|c|c|c|}
\hline & \multicolumn{2}{|c|}{ Recovered } & \multicolumn{2}{|c|}{ Died } & \multirow[t]{2}{*}{$p$ value $^{\mathrm{a}}$} \\
\hline & $n$ & $\%$ & $n$ & $\%$ & \\
\hline \multicolumn{6}{|c|}{ Dexamethasone } \\
\hline No & 374 & 56.2 & 107 & 40.5 & $<0.001$ \\
\hline Yes & 291 & 43.8 & 157 & 59.5 & \\
\hline
\end{tabular}

ECMO extracorporeal membrane oxygenation

${ }^{a}$ Fisher's exact test

Table 2 BMl and blood test data of patients

\begin{tabular}{|c|c|c|c|}
\hline & Recovered & Died & $p$ value \\
\hline \multicolumn{4}{|l|}{ BMI $\left(\mathrm{kg} / \mathrm{m}^{2}\right)$} \\
\hline$n$ & 197 & 100 & $0.01^{\mathrm{a}}$ \\
\hline Mean \pm SD & $23.5 \pm 5.3$ & $22.0 \pm 4.6$ & \\
\hline \multicolumn{4}{|l|}{ Alb (g/dL) } \\
\hline$n$ & 204 & 65 & $<0.001^{\mathrm{a}}$ \\
\hline Mean \pm SD & $3.3 \pm 0.6$ & $2.9 \pm 0.6$ & \\
\hline \multicolumn{4}{|l|}{ BUN (mg/dL) } \\
\hline$n$ & 208 & 94 & $0.018^{\mathrm{a}}$ \\
\hline Mean \pm SD & $56.4 \pm 19.7$ & $64.2 \pm 28.8$ & \\
\hline \multicolumn{4}{|l|}{$\mathrm{Cr}(\mathrm{mg} / \mathrm{dL})$} \\
\hline$n$ & 208 & 94 & $0.004^{\mathrm{a}}$ \\
\hline Mean \pm SD & $10.1 \pm 4.1$ & $8.8 \pm 3.5$ & \\
\hline \multicolumn{4}{|l|}{ CRP $(\mathrm{mg} / \mathrm{dL})$} \\
\hline$n$ & 202 & 92 & $<0.001^{b}$ \\
\hline Mean (IQR) & $2.0(0.6-6.2)$ & $7.1(3.0-12.8)$ & \\
\hline \multicolumn{4}{|l|}{ WBC $(/ \mu \mathrm{L})$} \\
\hline$n$ & 213 & 97 & $0.001^{b}$ \\
\hline Mean (IQR) & $5150(4000-6600)$ & $6600(4100-8920)$ & \\
\hline \multicolumn{4}{|l|}{$\mathrm{Hb}(\mathrm{g} / \mathrm{dL})$} \\
\hline$n$ & 214 & 96 & $0.775^{\mathrm{a}}$ \\
\hline Mean (IQR) & $11.2 \pm 2.7$ & $11.1 \pm 1.5$ & \\
\hline \multicolumn{4}{|l|}{ PLT (万/ $/ \mu \mathrm{L})$} \\
\hline$n$ & 214 & 97 & $0.018^{b}$ \\
\hline Mean (IQR) & $19.3 \pm 26.6$ & $21.2 \pm 38.1$ & \\
\hline
\end{tabular}

$B M I$ body mass index, Alb albumin, $B U N$ urea nitrogen, $C r$ creatinine, $C R P$ C-reactive protein, $W B C$ white blood cell count, $H b$ hemoglobin, $P L T$ platelet count, $S D$ standard deviation, IQR interquartile range

a Welch's $t$ test

${ }^{\mathrm{b}}$ Mann-Whitney's U-test

of those patients is shown in Table 4. The overall survival was significantly prolonged in the patient group who were treated with remdesivir than in the patient group who were not treated with remdesivir (HR: 0.45, $95 \%$ CI $0.26-0.80, p=0.004$ ) (Fig. 2). Moreover, the duration of hospitalization (mean \pm standard deviation) was $20.9 \pm 13.2$ days in the patient group who were treated with remdesivir, which was significantly shorter than $16.2 \pm 8.1$ days in the patient group who were not treated

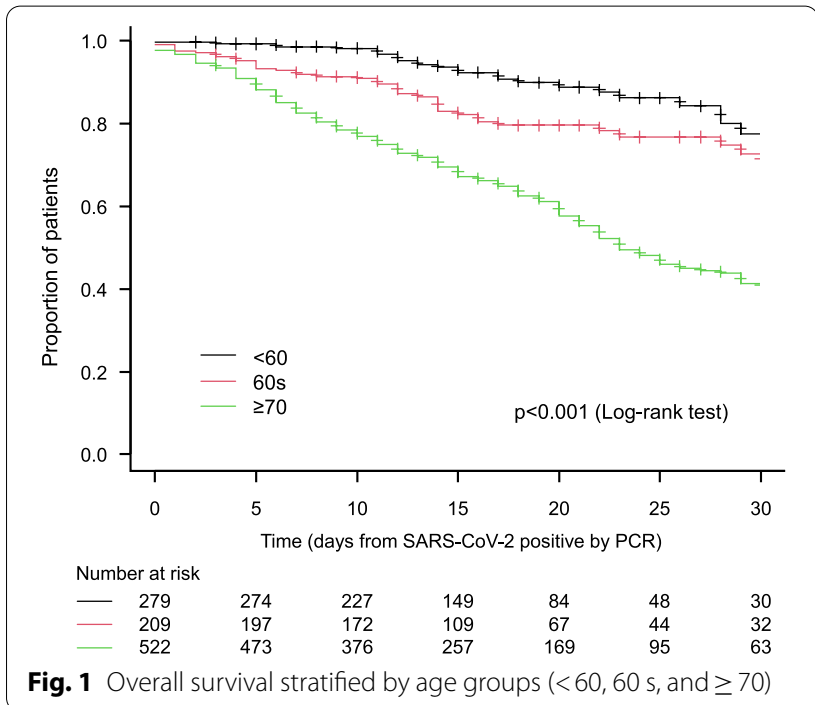

with remdesivir (Difference: 4.7 days, 95\% CI 2.2-7.4, $p<0.001)$.

\section{Predictive factors for mortality}

A total of 311 patients whose blood test data were available were analyzed. Among those patients, BMI was lower in the patient group who died. Multivariate analysis showed that the risk of mortality was increased with every 1 increment in BMI (HR: 1.10, 95\% CI 1.011.19). The risk of mortality was also increased with every 1 increment in CRP (HR 1.26, 95\% CI 1.01-1.56). On the other hand, the risk of mortality was decreased with every 1 increment in albumin (HR 0.48, 95\% CI 0.24-0.97) (Table 5).

\section{Overall survival in patients who underwent peritoneal dialysis or hemodialysis}

A total of 100 patients (25 patients in the patient group who underwent peritoneal dialysis and 75 patients in the patient group who underwent hemodialysis) were analyzed; the patients background is shown in Table 6 . Four deaths (20.0\%) were reported in the patient group who underwent peritoneal dialysis, while 16 deaths (21.3\%) were reported in the patient group who underwent hemodialysis. The overall survival was not significantly different between the patient groups who underwent peritoneal dialysis and those who underwent hemodialysis $(p=0.3)$ (Fig. 3). The overall survival was not significantly different in the patient group who underwent peritoneal dialysis compared to that in the patient group who underwent hemodialysis (HR: 0.61, 95\% CI $0.23-1.63)$. The duration of hospitalization 
Table 3 Multivariate analysis on predictive factors for mortality

\begin{tabular}{|c|c|c|c|c|}
\hline & \multirow[t]{2}{*}{ Hazard ratio } & \multicolumn{2}{|c|}{$95 \%$ confidence interval of hazard ratio } & \multirow[t]{2}{*}{$p$ value } \\
\hline & & Lower limit & Upper limit & \\
\hline \multicolumn{5}{|l|}{ Age (reference: <60) } \\
\hline $60 \mathrm{~s}$ & 1.58 & 0.90 & 2.77 & 0.109 \\
\hline$\geq 70$ & 4.92 & 3.10 & 7.80 & $<0.001$ \\
\hline Gender (reference: male) & 0.82 & 0.60 & 1.11 & 0.202 \\
\hline \multicolumn{5}{|c|}{ Primary disease (reference: chronic glomerulonephritis) } \\
\hline Diabetes mellitus & 1.16 & 0.46 & 2.95 & 0.751 \\
\hline Nephrosclerosis & 0.94 & 0.55 & 1.61 & 0.829 \\
\hline Others & 1.56 & 0.91 & 2.68 & 0.106 \\
\hline \multicolumn{5}{|l|}{ Duration of dialysis (reference: $<1$ year) } \\
\hline 1 to $<5$ years & 2.07 & 1.21 & 3.53 & 0.008 \\
\hline 5 to $<10$ years & 2.00 & 1.16 & 3.45 & 0.013 \\
\hline 10 to $<15$ years & 2.69 & 1.49 & 4.85 & 0.001 \\
\hline$\geq 15$ years & 2.68 & 1.48 & 4.88 & 0.001 \\
\hline \multicolumn{5}{|l|}{ Complication } \\
\hline Diabetes mellitus & 1.12 & 0.45 & 2.77 & 0.813 \\
\hline Hypertension & 0.87 & 0.65 & 1.16 & 0.337 \\
\hline Cardiovascular disease & 1.25 & 0.94 & 1.68 & 0.130 \\
\hline Chronic respiratory disease & 0.87 & 0.55 & 1.38 & 0.561 \\
\hline Peripheral arterial disease & 1.49 & 1.05 & 2.10 & 0.025 \\
\hline Malignancy & 0.91 & 0.62 & 1.33 & 0.626 \\
\hline \multicolumn{5}{|l|}{ Oxygenation (reference: no oxygenation) } \\
\hline Oxygen supplementation & 3.44 & 2.06 & 5.73 & $<0.001$ \\
\hline Ventilator or ECMO & 6.72 & 3.86 & 11.69 & $<0.001$ \\
\hline Remdesivir (reference: without remdesivir) & 0.60 & 0.37 & 0.98 & 0.041 \\
\hline $\begin{array}{l}\text { Dexamethasone (Reference: without dexa- } \\
\text { methasone) }\end{array}$ & 1.36 & 1.01 & 1.83 & 0.040 \\
\hline
\end{tabular}

Multivariate analysis was performed, with incidence of COVID-19 in facilities (less than 5 or more than 5 ), age $(<60,60 \mathrm{~s}, \geq 70)$, gender, primary disease (chronic glomerulonephritis, diabetes mellitus, nephrosclerosis, or others), duration of dialysis ( $<1$ year, 1 to $<5$ years, 5 to $<10$ years, 10 to $<15$ years, or $\geq 15$ years), complications (diabetes mellitus, hypertension, cardiovascular disease, peripheral arterial disease, or malignancy), oxygenation (with or without oxygen supplementation, ventilator, or ECMO), treatment for COVID-19 (with or without remdesivir or dexamethasone) as independent variables

ECMO extracorporeal membrane oxygenation

(mean \pm standard deviation) was $18.1 \pm 9.9$ days in the patient group who underwent peritoneal dialysis compared to $18.0 \pm 10.0$ days in the patient group who underwent hemodialysis; there was no significant difference between the groups $(p=0.96)$.

\section{Discussion}

Our study showed that the mortality rate among dialysis patients in Japan was high at $30.8 \%$, which was 20 times higher than the mortality rate of $1.5 \%$ in the general population for the same period, June 16, 2021 [5]. The mortality rate of dialysis patients by age group was $10.4 \%$ for those under $60,21.5 \%$ for those in their $60 \mathrm{~s}$, and $45.4 \%$ for those over 70 , while the mortality rate in the general population was $0.07 \%$ for those under 60 , $1.3 \%$ for those in their $60 \mathrm{~s}$, and $9.1 \%$ for those over
70, indicating a very high mortality rate for dialysis patients in all age groups [5]. However, Japan is not the only country with a high mortality rate among dialysis patients, and the data were similar to those in the USA and results of meta-analysis [6, 7]. The factors associated with increased risk of mortality were identified as aged over 70, having a long duration of dialysis, need of oxygenation, high CRP in laboratory data at diagnosis, high BMI, and complication of peripheral arterial disease. In a report on dialysis patients in the USA, complication of peripheral arterial disease was identified as an important risk factor [6]. In addition, hypercoagulation and vascular damage have been reported to be involved in the pathogenesis of COVID-19 [8], and thrombosis and elevated inflammatory response with CRP have been reported to be associated with worsening of symptoms [9-11]. Dialysis patients with 
Table 4 Background of patients stratified by administration of remdesivir (with or without remdesivir) after matching

\begin{tabular}{|c|c|c|c|c|c|}
\hline & \multicolumn{2}{|c|}{$\begin{array}{l}\text { Without } \\
\text { remdesivir }\end{array}$} & \multicolumn{2}{|c|}{$\begin{array}{l}\text { With } \\
\text { remdesivir }\end{array}$} & \multirow[t]{2}{*}{$p$ value $^{\mathrm{a}}$} \\
\hline & $n$ & $\%$ & $n$ & $\%$ & \\
\hline \multicolumn{6}{|l|}{ Age } \\
\hline$<60$ & 90 & 30.6 & 30 & 30.6 & 1.000 \\
\hline $60 \mathrm{~s}$ & 51 & 17.3 & 17 & 17.3 & \\
\hline$\geq 70$ & 153 & 52.0 & 51 & 52.0 & \\
\hline \multicolumn{6}{|l|}{ Gender } \\
\hline Male & 210 & 71.7 & 67 & 68.4 & 0.524 \\
\hline Female & 83 & 28.3 & 31 & 31.6 & \\
\hline \multicolumn{6}{|l|}{ Primary disease } \\
\hline Chronic glomerulonephritis & 40 & 15.1 & 20 & 22.5 & 0.372 \\
\hline Diabetes mellitus & 149 & 56.2 & 43 & 48.3 & \\
\hline Nephrosclerosis & 39 & 14.7 & 12 & 13.5 & \\
\hline Others & 37 & 14.0 & 14 & 15.7 & \\
\hline \multicolumn{6}{|l|}{ Duration of dialysis } \\
\hline$<1$ year & 37 & 12.9 & 14 & 14.4 & 0.754 \\
\hline 1 to $<5$ years & 100 & 34.8 & 31 & 32.0 & \\
\hline 5 to $<10$ years & 72 & 25.1 & 30 & 30.9 & \\
\hline 10 to $<15$ years & 42 & 14.6 & 13 & 13.4 & \\
\hline$\geq 15$ years & 36 & 12.5 & 9 & 9.3 & \\
\hline \multicolumn{6}{|l|}{ Complication } \\
\hline \multicolumn{6}{|l|}{ Hypertension } \\
\hline No & 156 & 55.1 & 42 & 42.9 & 0.046 \\
\hline Yes & 127 & 44.9 & 56 & 57.1 & \\
\hline \multicolumn{6}{|l|}{ Diabetes mellitus } \\
\hline No & 124 & 43.5 & 46 & 46.9 & 0.558 \\
\hline Yes & 161 & 56.5 & 52 & 53.1 & \\
\hline \multicolumn{6}{|l|}{ Cardiovascular disease } \\
\hline No & 156 & 56.5 & 49 & 51.6 & 0.406 \\
\hline Yes & 120 & 43.5 & 46 & 48.4 & \\
\hline \multicolumn{6}{|l|}{ Chronic respiratory disease } \\
\hline No & 249 & 89.6 & 83 & 87.4 & 0.571 \\
\hline Yes & 29 & 10.4 & 12 & 12.6 & \\
\hline \multicolumn{6}{|l|}{ Peripheral arterial disease } \\
\hline No & 230 & 84.9 & 75 & 78.9 & 0.201 \\
\hline Yes & 41 & 15.1 & 20 & 21.1 & \\
\hline \multicolumn{6}{|l|}{ Malignancy } \\
\hline No & 234 & 84.2 & 83 & 87.4 & 0.509 \\
\hline Yes & 44 & 15.8 & 12 & 12.6 & \\
\hline \multicolumn{6}{|l|}{ Number of complication } \\
\hline 0 & 38 & 13.1 & 10 & 10.2 & 0.778 \\
\hline 1 & 84 & 29.1 & 29 & 29.6 & \\
\hline$\geq 2$ & 167 & 57.8 & 59 & 60.2 & \\
\hline \multicolumn{6}{|l|}{ Oxygenation } \\
\hline No & 69 & 23.5 & 23 & 23.5 & 1.000 \\
\hline Yes & 159 & 54.1 & 53 & 54.1 & \\
\hline Ventilator or ECMO & 66 & 22.4 & 22 & 22.4 & \\
\hline
\end{tabular}

ECMO extracorporeal membrane oxygenation

${ }^{\text {a }}$ Fisher's exact test

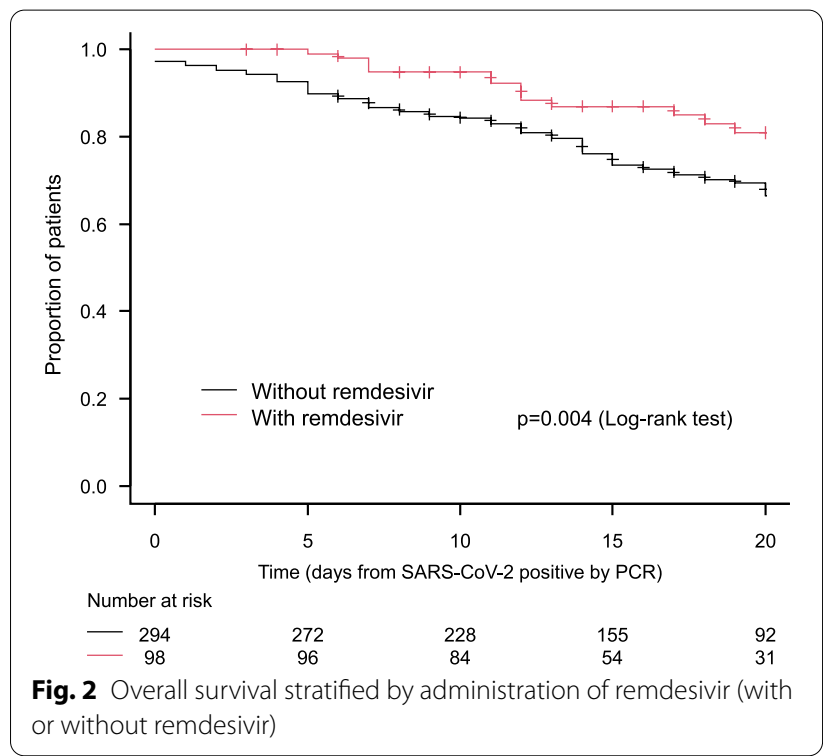

peripheral arterial disease often have concomitant systemic vascular disease and small artery disease, which might lead to increase the risk of mortality.

The results showed that the risk of mortality decreased as the albumin level increased. Since nutrition is an important factor related to immunity, and increase in CRP and complication of peripheral arterial disease are risk factors of mortality, malnutrition, inflammation, and atherosclerosis syndrome (MIA syndrome) known to occur in dialysis patients $[12,13]$ might lead to risk of increasing the severity of COVID-19 and mortality.

The mortality rate of patients with peritoneal dialysis was $16.0 \%$ ( $4 / 25$ patients), which is lower than $25 \%$ ( $2 / 8$ patients) in China [14] and $18.2 \%$ (2/11 patients) in the USA [15]; however, caution is needed to interpret these data due to small sample size. In Japan, the mortality risk was compatible among patients who underwent peritoneal dialysis and matched those who underwent hemodialysis, which might be because all dialysis patients diagnosed with COVID-19 were treated with hospitalization.

As for the prevalence rate of COVID-19, since the number of dialysis patients in Japan in 2020 and 2021 has not been reported yet, the calculation using the data as of December 31, 2019 [16] shows a lower prevalence rate of $0.25 \%(25 / 9746)$ in peritoneal dialysis compared to $0.57 \%$ $(1.948 / 344,640)$ in all dialysis patients. However, statistical analysis cannot be performed since the total number of dialysis patients at the time of COVID-19 occurrence (denominator) is unknown. The prevalence of a study of 810 patients with peritoneal dialysis in Wuhan, China, was reported to be $2.44 / 1000$ person-months [14], which 
Table 5 Multivariate analysis on predictive factors for mortality

\begin{tabular}{|c|c|c|c|c|}
\hline & \multirow[t]{2}{*}{ Hazard ratio } & \multicolumn{2}{|c|}{$\begin{array}{l}95 \% \text { confidence interval } \\
\text { of hazard ratio }\end{array}$} & \multirow[t]{2}{*}{$p$ value } \\
\hline & & Lower limit & Upper limit & \\
\hline \multicolumn{5}{|l|}{ Age (reference: <60) } \\
\hline $60 \mathrm{~s}$ & 2.73 & 0.96 & 7.79 & 0.061 \\
\hline$\geq 70$ & 6.03 & 1.98 & 18.42 & 0.002 \\
\hline $\begin{array}{l}\text { Gender (reference: } \\
\text { male) }\end{array}$ & 0.60 & 0.29 & 1.26 & 0.177 \\
\hline \multicolumn{5}{|c|}{ Primary disease (reference: chronic glomerulonephritis) } \\
\hline Diabetes mellitus & 1.08 & 0.46 & 2.54 & 0.866 \\
\hline Nephrosclerosis & 1.76 & 0.60 & 5.12 & 0.302 \\
\hline Others & 1.87 & 0.60 & 5.85 & 0.280 \\
\hline \multicolumn{5}{|c|}{ Duration of dialysis (reference: $<1$ year) } \\
\hline 1 to $<5$ years & 8.99 & 1.06 & 76.15 & 0.044 \\
\hline 5 to $<10$ years & 9.65 & 1.16 & 80.44 & 0.036 \\
\hline 10 to $<15$ years & 21.91 & 2.15 & 223.26 & 0.009 \\
\hline$\geq 15$ years & 22.76 & 2.50 & 207.23 & 0.006 \\
\hline \multicolumn{5}{|l|}{ Data } \\
\hline BMI & 1.10 & 1.01 & 1.19 & 0.021 \\
\hline Alb & 0.48 & 0.24 & 0.97 & 0.040 \\
\hline BUN & 1.02 & 1.00 & 1.04 & 0.039 \\
\hline $\mathrm{Cr}$ & 0.91 & 0.79 & 1.04 & 0.166 \\
\hline CRP (log) & 1.26 & 1.01 & 1.56 & 0.041 \\
\hline WBC (log) & 1.54 & 0.87 & 2.73 & 0.137 \\
\hline $\mathrm{Hb}$ & 1.06 & 0.87 & 1.30 & 0.565 \\
\hline PLT (log) & 1.09 & 0.66 & 1.82 & 0.730 \\
\hline
\end{tabular}

Multivariate analysis was performed, with age $(<60,60 \mathrm{~s}$, or $\geq 70)$, gender, primary disease (chronic glomerulonephritis, diabetes mellitus, nephrosclerosis, others), duration of dialysis ( $<1$ year, 1 to $<5$ years, 5 to $<10$ years, 10 to $<15$ years, or $\geq 15$ years), BMl, albumin, blood urea nitrogen, creatinine, CRP, white blood cell count, hemoglobin, and platelet count as independent variables

All data show hazard ratio for every 1 increase in value

$B M I$ body mass index, $A l b$ albumin, $B U N$ blood urea nitrogen, $C r$ creatinine, $C R P$ C-reactive protein, WBC white blood cell count, $H b$ hemoglobin, $P L T$ platelet count

is similar to that in patients with peritoneal dialysis in Japan.

Although the United States Food and Drug Administration (FDA) does not recommend remdesivir for patients with eGFR $<30 \mathrm{~mL} / \mathrm{min} / 1.73 \mathrm{~m}^{2}$, the safety and tolerability of remdesivir were investigated in 48 dialysis patients with COVID-19 by Aiswarya et al. [17]. The results showed that the duration of hospitalization was shortened by an average of 5.5 days in the patients who received remdesivir within $48 \mathrm{~h}$ of hospitalization compared to those who did not receive remdesivir within $48 \mathrm{~h}$ of hospitalization $(p=0.001)$, and the safety of remdesivir was also confirmed. Our study results with the propensity score matching demonstrated that duration of hospitalization was shortened by 4.7 days in the
Table 6 Background of patients stratified by dialysis treatment (peritoneal dialysis or hemodialysis) after matching

\begin{tabular}{|c|c|c|}
\hline Hemodialysis & $\begin{array}{l}\text { Peritoneal } \\
\text { dialysis }\end{array}$ & $p$ value $^{a}$ \\
\hline$\%$ & $n$ & \\
\hline
\end{tabular}

\begin{tabular}{|c|c|c|c|c|c|}
\hline \multicolumn{6}{|l|}{ Age } \\
\hline$<60$ & 36 & 48.0 & 12 & 48.0 & 1.000 \\
\hline $60 s$ & 21 & 28.0 & 7 & 28.0 & \\
\hline$\geq 70$ & 18 & 24.0 & 6 & 24.0 & \\
\hline \multicolumn{6}{|l|}{ Gender } \\
\hline Male & 55 & 73.3 & 20 & 80.0 & 0.601 \\
\hline Female & 20 & 26.7 & 5 & 20.0 & \\
\hline \multicolumn{6}{|l|}{ Primary disease } \\
\hline Chronic glomerulonephritis & 15 & 21.1 & 8 & 36.4 & 0.507 \\
\hline Diabetes mellitus & 36 & 50.7 & 8 & 36.4 & \\
\hline Nephrosclerosis & 6 & 8.5 & 2 & 9.1 & \\
\hline Others & 14 & 19.7 & 4 & 18.2 & \\
\hline \multicolumn{6}{|l|}{ Duration of dialysis } \\
\hline$<1$ year & 10 & 13.7 & 6 & 24.0 & 0.032 \\
\hline 1 to $<5$ years & 24 & 32.9 & 14 & 56.0 & \\
\hline 5 to $<10$ years & 22 & 30.1 & 5 & 20.0 & \\
\hline 10 to $<15$ years & 9 & 12.3 & 0 & 0.0 & \\
\hline$\geq 15$ years & 8 & 11.0 & 0 & 0.0 & \\
\hline \multicolumn{6}{|l|}{ Complication } \\
\hline \multicolumn{6}{|l|}{ Hypertension } \\
\hline No & 41 & 54.7 & 12 & 50.0 & 0.815 \\
\hline Yes & 34 & 45.3 & 12 & 50.0 & \\
\hline \multicolumn{6}{|l|}{ Diabetes mellitus } \\
\hline No & 36 & 48.0 & 16 & 66.7 & 0.159 \\
\hline Yes & 39 & 52.0 & 8 & 33.3 & \\
\hline \multicolumn{6}{|l|}{ Cardiovascular disease } \\
\hline No & 51 & 69.9 & 21 & 87.5 & 0.110 \\
\hline Yes & 22 & 30.1 & 3 & 12.5 & \\
\hline \multicolumn{6}{|l|}{ Chronic respiratory disease } \\
\hline No & 67 & 91.8 & 24 & 100.0 & 0.331 \\
\hline Yes & 6 & 8.2 & 0 & 0.0 & \\
\hline \multicolumn{6}{|l|}{ Peripheral arterial disease } \\
\hline No & 64 & 87.7 & 23 & 95.8 & 0.443 \\
\hline Yes & 9 & 12.3 & 1 & 4.2 & \\
\hline \multicolumn{6}{|l|}{ Malignancy } \\
\hline No & 65 & 90.3 & 23 & 95.8 & 0.675 \\
\hline Yes & 7 & 9.7 & 1 & 4.2 & \\
\hline \multicolumn{6}{|l|}{ Number of complications } \\
\hline 0 & 12 & 16.0 & 6 & 25.0 & 0.164 \\
\hline 1 & 25 & 33.3 & 11 & 45.8 & \\
\hline$\geq 2$ & 38 & 50.7 & 7 & 29.2 & \\
\hline \multicolumn{6}{|l|}{ Oxygenation } \\
\hline No & 12 & 16.0 & 4 & 16.0 & 1.000 \\
\hline Yes & 54 & 72.0 & 18 & 72.0 & \\
\hline Ventilator or ECMO & 9 & 12.0 & 3 & 12.0 & \\
\hline \multicolumn{6}{|l|}{ Remdesivir } \\
\hline No & 63 & 87.5 & 23 & 95.8 & 0.443 \\
\hline Yes & 9 & 12.5 & 1 & 4.2 & \\
\hline
\end{tabular}


Table 6 (continued)

\begin{tabular}{llclllll}
\hline & \multicolumn{3}{c}{ Hemodialysis } & \multicolumn{2}{l}{$\begin{array}{l}\text { Peritoneal } \\
\text { dialysis }\end{array}$} & p value \\
\cline { 2 - 3 } & $\boldsymbol{n}$ & $\%$ & & $\boldsymbol{n} \%$ & \\
\hline Dexamethasone & 27 & 37.5 & & 11 & 45.8 & 0.481 \\
No & 45 & 62.5 & & 13 & 54.2 & \\
Yes & & & & &
\end{tabular}

${ }^{a}$ Fisher's exact test

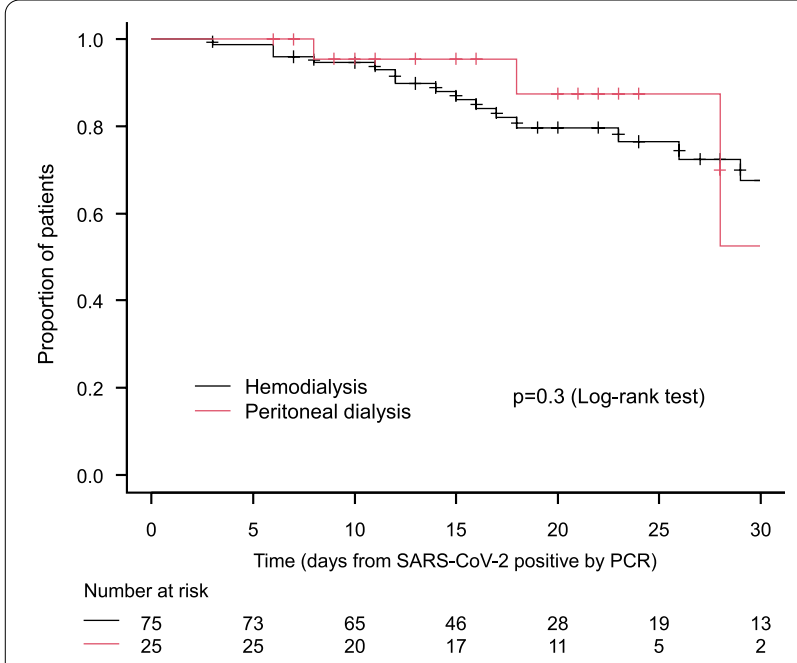

Fig. 3 Overall survival stratified by dialysis treatment (peritoneal dialysis or hemodialysis)

patients who received remdesivir compared to those who did not $(p<0.001)$. Moreover, the overall survival was significantly prolonged in the patients who received remdesivir compared to that in patients who did not receive remdesivir [HR: 0.45 (95\% CI $0.26-$ $0.80)$ ]. Remdesivir was confirmed to be an effective treatment option for dialysis patients in Japan.

In the case of COVID-19, the severity of the disease in dialysis patients is high and the risk of mortality is also high. Thus, it is important to take infection control measures to prevent the infection of SARS-CoV-2, and the COVID-19 Task Force Committee has been promoting awareness of infection control measures [18]. In addition, prevention of infection, onset of disease, and prevention of severe symptoms through vaccination are important. According to the surveillance of the COVID-19 Task Force Committee, the prevalence ratio of dialysis patients to the general population has decreased since 1 month after the vaccination in the elderly population aged over 65 years was started in Japan. In the third wave, December 2020 and January 2021 , there were 235,800 new cases were reported in the general population, while 720 new cases were reported in dialysis patients; the prevalence rate was
1 per 328 in the general population. However, in the fourth wave, May and June 2021, there were 225,006 new cases were reported in the general population and 330 new cases were reported in dialysis patients; the prevalence rate was 1 per 682 in the general population. This is thought to be due to the fact that the majority of dialysis patients had vaccination early since the proportion of population of dialysis patients aged over 65 years is twice as large as population of the general population aged over 65 years [18].

\section{Conclusion}

In conclusion, dialysis patients have a high severity of illness and a high risk of mortality in cases of COVID-19. Therefore, awareness and implementation of infection control measures are important. Treatment with remdesivir might be effective in shortening the duration of hospitalization and reducing the risk of mortality.

\section{Abbreviations}

BMI: Body mass index; COVID-19: New coronavirus disease; CRP: C-reactive protein; ECMO: Extracorporeal membrane oxygenation; SARS-CoV-2: Severe acute respiratory syndrome coronavirus 2.

\section{Acknowledgements}

We thank the staff members in the dialysis facilities that participated in this study.

\section{Authors' contributions}

All authors planned the study. KK analyzed and interpreted the data. KK mainly wrote the manuscript. KK and TY mainly coordinated within JADP. MR and HN mainly coordinated within JSDT. MN mainly coordinated within JSN. All authors contributed to this survey. All authors read and approved the final manuscript.

Funding

None.

Availability of data and materials

None.

\section{Declarations}

Ethics approval and consent to participate

This study was approved by the Ethics Committee of the Japanese Society for Dialysis Therapy (authorization number: 1-8), and all procedures adhered to the Declaration of Helsinki.

\section{Consent for publication}

Not applicable.

\section{Competing interests \\ None.}

\section{Author details}

${ }^{1}$ Division of Nephrology, Shimoochiai Clinic, 2-1-6 Shimoochiai, Shinjuku-ku, Tokyo 161-0033, Japan. ${ }^{2}$ Division of Nephrology and Endocrinology, The University of Tokyo Graduate School of Medicine, Tokyo, Japan. ${ }^{3}$ Department of Nephrology, Tokyo Saiseikai Central Hospital, Tokyo, Japan. ${ }^{4}$ Kidney Center, Shirasagi Hospital, Osaka, Japan. ${ }^{5}$ Nagoya Memorial Hospital, Nagoya, Japan. ${ }^{6}$ Department of Blood Purification, Tokyo Women's Medical University, Tokyo, Japan. ${ }^{7}$ Department of Nephrology, Faculty of Medicine, $T o h o$ University,

Tokyo, Japan. ${ }^{8}$ Department of Nephrology, Tokyo Medical University, Tokyo, 
Japan. ${ }^{9}$ Department of Nephrology, Seishokai Memorial Hospital, Tokyo, Japan. ${ }^{10}$ Faculty of Medical and Health Sciences, Tsukuba International University, Tsuchiura, Japan. ${ }^{11}$ Department of General Internal Medicine, Saitama Medical University, Iruma, Japan. ${ }^{12}$ Division of Nephrology, Department of Medicine, Showa University School of Medicine, Tokyo, Japan.

Received: 30 Auqust 2021 Accepted: 7 October 2021

Published online: 21 October 2021

\section{References}

1. World Health Organization (WHO). Coronavirus disease (COVID-19) Pandemic. https://www.who.int/emergencies/diseases/novel-coron avirus-2019. Accessed 14 Aug 2021.

2. The Japanese Ministry of Health Labour and Welfare. Current status of COVID-19 in the general population in Japan (as of Aug 14, 2021). https:// www.mhlw.go.jp/stf/newpage_20461.html. Accessed 14 Aug 2021. (in Japanese)

3. Kikuchi K, Nangaku M, Ryuzaki M, Yamakawa T, Hanafusa N, Sakai K, et al. Current status and guidance on preventive measures. Ther Apher Dial. 2020;24(4):361-5.

4. Kikuchi K, Nangaku M, Ryuzaki M, Yamakawa T. COVID-19 task force committee of the Japanese association of dialysis physicians; the Japanese society for dialysis therapy; the Japanese society of nephrology cumulative number of COVID-19 in dialysis patients. https://jsn.or.jp/medic/data/ COVID-19number-of-infected_20210813.pdf. Accessed 14 Aug 2021. (in Japanese).

5. The Japanese Ministry of Health Labour and Welfare. Outbreak trends of COVID-19 in the general population in Japan (as of Aug 14, 2021). https:// www.mhlw.go.jp/content/10906000/000793909.pdf. Accessed 14 Aug 2021. (in Japanese).

6. Hsu CM, Weiner DE, Aweh G, Miskulin DC, Manley HJ, Stewart C, et al. COVID-19 among US dialysis patients: risk factors and outcomes from a national dialysis provider. Am J Kidney Dis. 2021;77(5):748-56.

7. Chung EY, Palmer SC, Natale P, Krishnan A, Cooper TE, Saglimbene VM, et al. Incidence and outcomes of COVID-19 in people with CKD: a systematic review and meta-analysis. Am J Kidney Dis. 2021. https://doi.org/10. 1053/j.ajkd.2021.07.003.

8. Bonaventura A, Vecchié A, Dagna L, Martinod K, Dixon DL, Van Tassell BW, et al. Endothelial dysfunction and immunothrombosis as key pathogenic mechanisms in COVID-19. Nat Rev Immunol. 2021;21(5):319-29.
9. Nopp S, Moik F, Jilma B, Pabinger I, Ay C. Risk of venous thromboembolism in patients with COVID-19: a systematic review and meta-analysis. Res Pract Thromb Haemost. 2020:4(7):1178-91.

10. Liu YP, Li GM, He J, Liu Y, Li M, Zhang R, et al. Combined use of the neutrophil-to-lymphocyte ratio and CRP to predict 7-day disease severity in 84 hospitalized patients with COVID-19 pneumonia: a retrospective cohort study. Ann Transl Med. 2020;8(10):635.

11. Valeri AM, Robbins-Juarez SY, Stevens JS, Ahn W, Rao MK, Radhakrishnan $J$, et al. Presentation and outcomes of patients with ESKD and COVID-19. J Am Soc Nephrol. 2020;31(7):1409-15.

12. Stenvinkel $P$, Heimburger $O$, Lindholm B, Kaysen GA, Bergström J. Are there two types of malnutrition in chronic renal failure? Evidence for relationships between malnutrition, inflammation and atherosclerosis (MIA syndrome). Nephrol Dial Transplant. 2000;15(7):953-60.

13. Tonbul HZ, Demir M, Altintepe L, Güney I, Yeter E, Türk S, et al. Malnutrition-inflammation-atherosclerosis (MIA) syndrome components in hemodialysis and peritoneal dialysis patients. Ren Fail. 2006;28(4):287-94.

14. Jiang HJ, Tang H, Xiong F, Chen WL, Tian JB, Sun J, et al. COVID-19 in peritoneal dialysis patients. Clin J Am Soc Nephrol. 2020;16(1):121-3.

15. Sachdeva M, Uppal NN, Hirsch JS, Ng JH, Malieckal D, Fishbane S, et al. COVID-19 in hospitalized patients on chronic peritoneal dialysis: a case series. Am J Nephrol. 2020;51(8):669-74.

16. The Japanese Society for Dialysis Therapy. Annual dialysis data report 2019, JSDT Renal Data Registry. https://docs.jsdt.or.jp/overview/file/2019/ pdf/01.pdf. Accessed 14 Aug 2021. (in Japanese).

17. Aiswarya D, Arumugam V, Dineshkumar T, Gopalakrishnan N, Lamech TM, Nithya G, et al. Use of remdesivir in patients with COVID-19 on hemodialysis: a study of safety and tolerance. Kidney Int Rep. 2021;6(3):586-93.

18. Kikuchi K, Nangaku M, Ryuzaki M, Yamakawa T. COVID-19 task force committee of the Japanese association of dialysis physicians; the Japanese society for dialysis therapy; the Japanese society of nephrology current status and preventive measures COVID-19 in dialysis facilities. http:// www.touseki-ikai.or.jp/htm/03_info/doc/20210802_current_status_of hospitalization_adjustment.pdf. Accessed 14 Aug 2021. (in Japanese).

\section{Publisher's Note}

Springer Nature remains neutral with regard to jurisdictional claims in published maps and institutional affiliations.
Ready to submit your research? Choose BMC and benefit from:

- fast, convenient online submission

- thorough peer review by experienced researchers in your field

- rapid publication on acceptance

- support for research data, including large and complex data types

- gold Open Access which fosters wider collaboration and increased citations

- maximum visibility for your research: over 100M website views per year

At $B M C$, research is always in progress.

Learn more biomedcentral.com/submissions 